\title{
Institutional Support for Online Teaching in Quality Assurance Frameworks
}

\author{
Neuza Sofia Pedro \\ University of Lisbon \\ Swapna Kumar \\ University of Florida
}

\begin{abstract}
The widespread growth of online education at higher education institutions necessitates institutional support for the development, implementation, and sustenance of online education. Faculty who teach online are at the forefront of implementation and play a critical role in online student success. In this scoping review, 13 online education quality frameworks were analyzed for the types of support needed by higher education faculty who teach online. The results are discussed in the context of implications for ensuring quality online education at higher education institutions.
\end{abstract}

Keywords: faculty support, online education, quality assurance, online teaching, e-learning, instructor support, institutional support

Pedro, N.S. \& Kumar, S. (2020). Institutional support for online teaching in quality assurance frameworks. Online Learning, 24(3), 50-66. https://doi.org/10.24059/olj.v24i3.2309

\section{Institutional Support for Online Teaching in Quality Assurance Frameworks}

Online education has experienced tremendous growth in the last two decades, with at least 31.6 percent of students taking online courses in the United States in 2016 (Seaman, Allen, \& Seaman, 2018). Over one-fifth of the U.S. higher education institutions $(n=280)$ surveyed in the 2019 CHLOE report (Garrett, Legon, \& Frederickson, 2019) reported that more than 50\% of their courses were offered online, and that between spring 2017 and 2018, the median growth rate of enrollment in fully online courses was 10\%. Higher education institutions (HEI) around the world are expanding their online course offerings, accompanied by increased scrutiny into quality and accountability (Shelton, 2011). The transition to online education necessitates changes within institutions and the provision of various types of support for stakeholders (e.g., faculty, students) and processes (e.g., course development) to ensure its success. In this article we focus on the types of institutional support for faculty who teach online at HEIs that are described in online education quality frameworks. 


\section{Faculty Support for Online Teaching}

Notwithstanding the importance of technology, infrastructure, instructional design, and standards for online course design, the faculty teaching online courses play a crucial role in the success of the courses and in student learning (Kibaru, 2018). They are integral to all aspects of an online course and to student engagement and success, acting as the subject matter expert, course designer, course manager, and facilitator (Martin, Budhrani, Kumar, \& Ritzhaupt, 2019; Phirangee, Epp, \& Hewitt, 2016). Although faculty roles might vary depending on institutional structures and academic policies, effective systems and supports are needed to ensure that they are able to successfully teach in online environments that are student-centered and interaction focused (Beck \& Ferdig, 2008). When an institution transitions to online education, or when programs decide to offer online courses, it is the faculty who are at the forefront of that change, needing to reconceptualize what they teach, how to teach it, how to assess student learning, and how to facilitate that learning in the online environment that requires a paradigm shift (Kibaru, 2018). The time taken to develop an online course and to teach it well has been acknowledged as more than that needed in an on-campus course (Seaman, 2009). The perceived and/or real increase in workload required in online teaching and the lack of recognition and institutional support for faculty teaching online have been identified as two of the most significant barriers in online education (Bolliger \& Wasilik, 2009).

There is an abundance of research in the last two decades on the barriers faced by faculty when they teach online and the need for faculty support and professional development (Berge, Muilenberg, \& Haneghan, 2002; Kebritchi, Lipschuetz, \& Santiague, 2017; Lloyd, Byrne, \& McCoy, 2012). Faculty lack technical skills, pedagogical skills for the paradigm shift in the online environment, incentives and resources to compensate for the time invested in developing and teaching an online course, and other supports for academic and administrative processes when transitioning to online teaching (Kebritchi et al., 2017; Lloyd et al., 2012; Seaman, 2009). Support for faculty is therefore extremely important for online education to succeed at an HEI, and especially so for faculty with little or no online teaching experience (Hunt et al., 2014; Martin \& Parker, 2014). Faculty development and training have been reported to be a top priority of all types of HEI, followed by resources for instructional design and faculty support, but such training and support vary widely across different types of HEI and contexts (Garrett et al., 2019). Additionally, there are other forms of institutional support that contribute to online instructors' success in online teaching. In reviewing the literature, we found several different studies that called for such support. However, we identified a lack of systemized knowledge pertaining to instructional services that should be provided by HEI to assure high quality online teaching.

Faculty support can take many forms - course development support, time and rewards for engagement in online teaching, professional development for skill development in online teaching, help with academic processes (e.g., plagiarism prevention, fair use of materials), institutional guidance on policies in online education, operational support, peer support, and even student support (Almpanis, 2015; Baran \& Correia, 2014; Fetzner, 2003; Lion \& Stark, 2010; Seaman, 2009; Wang, Gould, \& King, 2010). Online student support with administrative and academic processes, technology access, and in some cases, advising, can greatly reduce the questions and concerns that faculty teaching online courses deal with, and thus their workload. Furthermore, it is important that these different forms of support for faculty are in some way coordinated and are part of the strategic goals and direction at an institution (Hartman et al., 2014; Orr, Williams, \& Pennington, 2009). Leadership and institutional positioning as well as institutional support have 
been highlighted by both administrators and faculty in the research as essential for online instructor success (Hicks, 2009; Kibaru, 2018; Orr et al., 2009). Such support contributes to faculty satisfaction, which is a key indicator of quality in online learning (Bolliger \& Wasilik, 2009) and one of the five pillars of quality online education according to the Online Learning Consortium (https://onlinelearningconsortium.org/about/quality-framework-five-pillars/).

Faculty support has been identified as a key indicator of quality online learning (Martin, Polly, Jokiaho \& May, 2017) as well as a critical factor for successful online learning (Daniel \& Uvalic-Trumbic, 2013). Individual studies have focused on various forms of instructional design support or faculty development for online teaching, but it is important to comprehensively identify what constitutes faculty support at an HEI aiming for quality online education. The purpose of this study is to identify the institutional support services that help faculty practice quality online teaching that are included in online quality assurance frameworks and systematically detail such support. In a context where an increasing number of HEIs across the world are adopting online education, and HEIs already in the online education space expand their online offerings, information about quality in faculty support of online teaching can be valuable to institutions, administrators, and faculty engaged in online education. This is particularly significant during the COVID-19 pandemic where large numbers of faculty are expected to transition to emergency remote teaching (Hodges et al., 2020) in the short-term and online teaching in the long-term.

\section{Research Question}

In this paper, we conducted a scoping review of frameworks, guidelines, and standards related to quality in online education to answer the research question:

What institutional services are identified in online quality assurance frameworks as supporting quality online teaching in higher education?

\section{Methods}

A scoping review is an increasingly-used literature review approach to map broader topics that are of a complex or heterogenous nature (Arksey \& O'Malley, 2005; Peterson, Pearce, Ferguson \& Langford, 2016). It allows for the inclusion of various types of literature that can be theoretical, empirical, and "gray literature" and is particularly relevant for "practice, education, research, and policy" (Peterson et al., 2016, p. 12). Arksey and O'Malley's (2005) framework and methodological enhancements by Levac, Colquhoun, and O'Brien (2010) were used in this stepby-step approach to conduct the scoping review. Two independent reviewers engaged in all steps

of the process and met regularly to discuss their results and establish agreement before proceeding to the next phase (Colquhoun et al., 2014).

After identifying the broad research question, an online search was conducted in the search engine Google to identify relevant documents. This scoping review focused on a corpus of international frameworks, standards, and guidelines for the quality assurance of online education in higher education contexts. Searches were not conducted within academic databases because the literature being scoped was of a nature that could have been published outside research journals, or, in fact, would have most likely not been published within academic journals. The search was conducted in English, Portuguese, and Spanish, using the following combinations of keywords to encompass phrases used to describe online education across the world: "e-learning or distance learning or distance education or online education or online learning" + "Quality assurance." Two 
filters were applied: under "usage rights" the option "free to access, share or modify" was selected and under "terms appearing" the option "in the text on the page" was selected. The first five pages of results of each online search, a total of 82 sources, were then analyzed.

\section{Exclusion and Inclusion Criteria}

The selection process included exclusion criteria and inclusion criteria that were applied to the 82 relevant sources retrieved about quality assurance in online education. Two independent reviewers engaged in the application of the previously agreed exclusion and inclusion criteria for the eligibility process. Exclusion criteria were first applied as follows:

(a) the framework should have a broad scope and not address only a specific aspect of online education (e.g., learning management system quality, online course design);

(b) the framework should not be more than 20 years old (only sources between 1999 and 2019 were included);

(c) the framework should not be a result of an empirical study by an individual researcher, and;

(d) the frameworks should not have been developed for use within specific universities.

The goal was to identify broadly used and accepted frameworks that were not specific to one study or one university, however valuable or empirically significant. A total of 16 documents encompassing frameworks, standards or guidelines were found to be eligible by both reviewers (Table 1). 
Table 1

Online Education Quality Assurance Frameworks After Exclusion Criteria

\begin{tabular}{|c|c|c|c|c|c|}
\hline Nr. & Title & Organization & $\begin{array}{l}\text { Country/ } \\
\text { Region }\end{array}$ & Year & Retrieved from \\
\hline 1 & $\begin{array}{l}\text { Canadian } \\
\text { Recommended E- } \\
\text { learning Guidelines }\end{array}$ & $\begin{array}{l}\text { Canadian Association for } \\
\text { Community Education }+ \\
\text { Office of Learning } \\
\text { Technologies of Human } \\
\text { Resources Development } \\
\text { Canada }\end{array}$ & Canada & 2002 & $\begin{array}{l}\text { https://www.futured.com/p } \\
\text { df/CanREGs\%20Eng.pdf }\end{array}$ \\
\hline 2 & $\begin{array}{l}\text { Quality on the Line; } \\
\text { Benchmarks for } \\
\text { Success in Internet- } \\
\text { based Distance } \\
\text { Education }\end{array}$ & $\begin{array}{l}\text { Institute for Higher } \\
\text { Education Policy }\end{array}$ & USA & 2000 & $\begin{array}{l}\text { http://www.ihep.org/resear } \\
\text { ch/publications/quality- } \\
\text { line-benchmarks-success- } \\
\text { internet-based-distance- } \\
\text { education }\end{array}$ \\
\hline 3 & $\begin{array}{l}\text { Quality Scorecard for } \\
\text { Online Learning } \\
\text { Programs }\end{array}$ & Online Learning Consortium & USA & 2017 & $\begin{array}{l}\text { https://onlinelearningconso } \\
\text { rtium.org/consult/qs- } \\
\text { navigator/ }\end{array}$ \\
\hline 4 & $\begin{array}{l}\text { National Standards for } \\
\text { Quality Online } \\
\text { Programs + Online } \\
\text { Teaching }\end{array}$ & $\begin{array}{l}\text { National Standards for } \\
\text { Quality Online Learning }\end{array}$ & USA & 2019 & $\begin{array}{l}\text { https://www.inacol.org/res } \\
\text { ource/inacol-national- } \\
\text { standards-for-quality- } \\
\text { online-programs/ }\end{array}$ \\
\hline 5 & $\begin{array}{l}\text { Quality Assurance } \\
\text { Toolkit for Open and } \\
\text { Distance Nonformal } \\
\text { Education }\end{array}$ & Commonwealth of Learning & $\begin{array}{l}\text { Intergove } \\
\text { rnmental } \\
\text { Organisat } \\
\text { ion }\end{array}$ & 2012 & $\begin{array}{l}\text { http://oasis.col.org/handle/ } \\
\text { 11599/106 }\end{array}$ \\
\hline 6 & $\begin{array}{l}\text { Quality Assurance in } \\
\text { Open and Distance } \\
\text { Learning }\end{array}$ & Commonwealth of Learning & $\begin{array}{l}\text { Intergove } \\
\text { rnmental } \\
\text { Organisat } \\
\text { ion }\end{array}$ & 2019 & $\begin{array}{l}\text { http://oasis.col.org/handle/ } \\
11599 / 103\end{array}$ \\
\hline 7 & $\begin{array}{l}\text { Sequent Handbook for } \\
\text { Quality in E-Learning } \\
\text { Procedures }\end{array}$ & $\begin{array}{l}\text { European Association of } \\
\text { Distance Teaching } \\
\text { Universities }\end{array}$ & $\mathrm{EU}$ & 2015 & $\begin{array}{l}\text { https://www.sequent- } \\
\text { network.eu/images/Guideli } \\
\text { nes/Sequent_Handbook_fo } \\
\text { r_Quality_in_e- } \\
\text { learning_procedures.pdf }\end{array}$ \\
\hline 8 & $\begin{array}{l}\text { Quality Assessment for } \\
\text { E-Learning: } \\
\text { A Benchmarking } \\
\text { Approach-Excellence } \\
\text { (3rd Ed.) }\end{array}$ & $\begin{array}{l}\text { European Association of } \\
\text { Distance Teaching } \\
\text { Universities }\end{array}$ & EU & 2016 & $\begin{array}{l}\text { https://e- } \\
\text { xcellencelabel.eadtu.eu/too } \\
\text { ls/manual }\end{array}$ \\
\hline 9 & $\begin{array}{l}\text { Considerations for } \\
\text { Quality Assurance of } \\
\text { E-Learning Provision }\end{array}$ & $\begin{array}{l}\text { European Association for } \\
\text { Quality Assurance in Higher } \\
\text { Education }\end{array}$ & EU & 2018 & $\begin{array}{l}\text { https://enqa.eu/indirme/pap } \\
\text { ers-and-reports/occasional- } \\
\text { papers/Considerations\%20f } \\
\text { or\%20QA } \% 20 \text { of } \% 20 \mathrm{e}- \\
\text { learning\%20provision.pdf }\end{array}$ \\
\hline
\end{tabular}


10 ACODE Benchmarks

for Technology

Enhanced Learning

11 E-Learning Capability: Informing and Guiding E-Learning Architectural Change and Development

12 AVU Quality

Assurance Framework for Open, Distance and eLearning Programmes

13 Distance Higher Education Programmes in a Digital Era: Good Practice Guide
Australasian Council on Open, Distance and elearning

New Zealand Ministry of

Education + Victoria

University of Wellington

African Virtual University

South Africa

South

Africa

Africa

2014

New

Zealand

Africa

(2014

Council on Higher Education

(1)
14 Asian Association of Open Universities Quality Assurance framework
Instrumento de Avaliação Institucional ExternaPresencial e a distância

Principios y estándares para la evaluación de programas educativos en las instituciones de educación superior 2017 - Modalidad a distancia

\section{Asian Association of Open Asia} Universities

Ministério da Educação e Cultura + Inep + DAES

\section{CIEES - Comités}

Interinstitucionales para la Evaluación de la Educación Superior

\section{Brazil 2017 http://inep.gov.br/instrume ntos 1}

https://www.acode.edu.au/ $\mathrm{mod} /$ resource/view.php?id $=193$

https://www.educationcoun ts.govt.nz/publications/eLearning/58139

http://www.avu.org/avuwe b/wpcontent/uploads/2016/05/Q A_FRAMEWORK.pdf https://www.che.ac.za/med ia_and_publications/frame works-criteria/distancehigher-educationprogrammes-digital-eragood

http://aaou.upou.edu.ph/qu ality-assurance-framework/

https://ciees.edu.mx/wp-
content/uploads/2018/07/Pr
incipios-y-
esta\%CC\%81ndares-para-
la-evaluacio\%CC\%81n-de-
programas-educativos-a-
distancia-en-las-
instituciones-de-
educacio\%CC\%81n-
superior-2017.pdf

These 16 frameworks were then screened in detail using the following inclusion criteria:

(a) The document presents a framework, standards, guidelines or criteria checklist for quality assurance in online education, online programs, or e-learning;

(b) The framework should have been developed by an organization, governmental organization, or entity that assumes a national or international regulatory role in the area of online education, therefore the framework is used for approval, assurance or evaluation of quality in online education, online programs, or e-learning;

(c) The framework is currently applied or can be applied across countries, even if developed within a country or region;

(d) The framework focuses addresses the quality assurance of online education, online programs, or e-learning in higher education. 
The two reviewers independently reviewed the 16 frameworks for each criterion using a binary scale ( 1 point for each criterion matched and 0 if no match found). Frameworks that were found by both reviewers to fulfill at least three criteria (scored 3 or 4 points) were considered eligible for further analysis. The final list of 13 frameworks are listed in Table 2.

Table 2

Eligible Online Education Quality Assurance Frameworks

Nr. Title Criteria

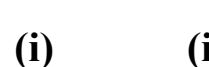

(i) (ii)

Total

\begin{tabular}{|c|c|c|c|c|c|c|}
\hline & & (i) & (ii) & (iii) & (iv) & Score \\
\hline 1 & $\begin{array}{l}\text { Canadian Recommended E-Learning } \\
\text { Guidelines }\end{array}$ & 1 & 1 & 1 & 1 & 4 \\
\hline 2 & Quality on the Line & 1 & 1 & 1 & 1 & 4 \\
\hline 3 & $\begin{array}{l}\text { Quality Scorecard for Online Learning } \\
\text { Programs }\end{array}$ & 1 & 1 & 1 & 1 & 4 \\
\hline 4 & $\begin{array}{l}\text { Quality Assurance in Open and } \\
\text { Distance Learning }\end{array}$ & 1 & 0 & 1 & 1 & 3 \\
\hline 5 & $\begin{array}{l}\text { Sequent Handbook for Quality in E- } \\
\text { learning procedures }\end{array}$ & 1 & 0 & 1 & 1 & 3 \\
\hline 6 & $\begin{array}{l}\text { Quality Assessment for E-learning: a } \\
\text { benchmarking approach - Excellence } \\
\left(3^{\text {rd }} \text { ed. }\right)\end{array}$ & 1 & 0 & 1 & 1 & 3 \\
\hline 7 & $\begin{array}{l}\text { Considerations for quality assurance of } \\
\text { e-learning provision }\end{array}$ & 1 & 1 & 1 & 1 & 4 \\
\hline 8 & $\begin{array}{l}\text { ACODE Benchmarks for Technology } \\
\text { Enhanced Learning }\end{array}$ & 1 & 1 & 1 & 1 & 4 \\
\hline 9 & $\begin{array}{l}\text { AVU Quality Assurance Framework for } \\
\text { Open, Distance and eLearning } \\
\text { Programmes }\end{array}$ & 1 & 0 & 1 & 1 & 3 \\
\hline 10 & $\begin{array}{l}\text { Distance Higher Education Programmes } \\
\text { in a Digital Era: Good Practice Guide }\end{array}$ & 1 & 1 & 0 & 1 & 3 \\
\hline 11 & $\begin{array}{l}\text { Asian Association of Open Universities } \\
\text { Quality Assurance framework }\end{array}$ & 1 & 1 & 1 & 1 & 4 \\
\hline 12 & $\begin{array}{l}\text { Instrumento de Avaliação } \\
\text { Institucional Externa- Presencial e a } \\
\text { distância }\end{array}$ & 1 & 1 & 0 & 1 & 3 \\
\hline 13 & $\begin{array}{l}\text { Principios y estándares para la } \\
\text { evaluación de programas educativos en } \\
\text { las instituciones de educación superior } \\
2017 \text { - Modalidad a distancia }\end{array}$ & 1 & 1 & 0 & 1 & 3 \\
\hline
\end{tabular}


The 13 international quality assurance frameworks were then analyzed with the aim of identifying the types of institutional support that are needed to ensure high quality online teaching and are important for faculty who teach online. The "population of interest" in this scoping review was faculty or instructors who teach online (Cacchione, 2016). The goal was thus to analyze all the information within each framework relevant to support for faculty or instructors who teach online, and that could ensure quality online teaching. While it can be argued that all support services involved in online education holistically contribute to supporting online teaching by faculty, the institutional support services that were listed as relevant for assuring quality in online teaching from a faculty perspective within the 13 frameworks and also those in prior research that were identified in the frameworks were the focus of this analysis. Although much of the data might also be relevant to other aspects of support in online education, the analysis and thus the results presented in this paper pertain specifically to institutional support services for online teaching and faculty. Various terms and designations were used to describe this population in the international frameworks analyzed across geographies. They were described as faculty members, professors, academic staff, online instructors, teaching staff, teachers, lecturers, staff members, and tutors.

\section{Results}

The quality frameworks, guidelines, or standards found were representative of all the continents: four in North America, two in Central and South America, three in Europe, two in Africa, and one each in Asia and Australia. The analysis of the institutional support services in the 13 frameworks that are relevant for assuring quality in online teaching from a faculty perspective is listed in Table 3 and described below.

\section{Technologies and Technical Support}

All 13 frameworks included technologies crucial to online education, which are described as "learning management systems and their associated systems; library systems; cloud-based tools and services; mobile technologies, hardware (computers, telecommunications and ancillary equipment) and networks, both internal and external" (Framework 8, p. 20). Technical support for faculty and students to successfully access and use the infrastructure, technologies, and networks for online education are important for quality online education at an institution. Additionally, technical support should constantly be updated and aligned to fulfill the needs of faculty and staff at an institution (Framework 8).

\section{Online Program/Course Effectiveness or Evaluation Data}

All 13 frameworks included recommendations for the regular collection of data in online programs and courses to evaluate their effectiveness and ensure their quality. For example, Framework 2 states, "The program's educational effectiveness and teaching/learning process is assessed through an evaluation process that uses several methods and applies specific standards" (p. 12). In addition to quality assurance benefits, the availability of such data can be valuable for faculty who teach online and who wish to continuously improve their courses and online teaching practices. In this regard, it is important that faculty have access to such data that is collected at the institution. Additionally, two frameworks mentioned the use of learning analytics support for course improvement. The use of learning analytics can be very useful for the improvement of online course design and teaching. However, support should be provided to faculty or professional development can be provided to faculty about how to view, download, and interpret the data. 
Table 3

\section{Institutional Support for Quality Online Teaching}

\begin{tabular}{|c|c|c|c|}
\hline Types of support & $\begin{array}{l}\text { Frameworks (1-13) from } \\
\text { Table 2 }\end{array}$ & $\begin{array}{l}\text { Total } \\
\text { occurrences }\end{array}$ & Percentage \\
\hline $\begin{array}{l}\text { Technical support for faculty and } \\
\text { students }\end{array}$ & (1 to 13 ) & 13 & $100 \%$ \\
\hline $\begin{array}{l}\text { Online course or program } \\
\text { effectiveness/assessment data } \\
\text { collection }\end{array}$ & (1 to 13 ) & 13 & $100 \%$ \\
\hline $\begin{array}{l}\text { Guidelines/standards for online } \\
\text { course design }\end{array}$ & $\begin{array}{l}\text { (1); (2); (3); (4); (5); (6); (7); } \\
\text { (8); (9); (10); (11); (13) }\end{array}$ & 12 & $92 \%$ \\
\hline $\begin{array}{l}\text { Administrative and academic } \\
\text { support for online students }\end{array}$ & $\begin{array}{l}\text { (1); (2); (3); (4); (5); (6); (7); } \\
(8) ;(9) ;(10) ;(12) ;(13)\end{array}$ & 12 & $92 \%$ \\
\hline $\begin{array}{l}\text { Development and training for } \\
\text { faculty in online course } \\
\text { development and teaching }\end{array}$ & $\begin{array}{l}\text { (1); (2); (3); (4); (5); (6); (7); } \\
\text { (8); (9); (10); (11) }\end{array}$ & 11 & $85 \%$ \\
\hline $\begin{array}{l}\text { Availability of online tutors or } \\
\text { tutoring services }\end{array}$ & $\begin{array}{l}(3) ;(4) ;(5) ;(6) ;(7) ;(8) ; \\
(10) ;(12) ;(13)\end{array}$ & 9 & $69 \%$ \\
\hline Online library support & $\begin{array}{l}\text { (1); (2); (3); (4); (5); (6); (7); } \\
\text { (10); (13) }\end{array}$ & 9 & $69 \%$ \\
\hline Online student advising services & $\begin{array}{l}\text { (1); (2); (3); (5); (6); (7); } \\
\text { (11);(13) }\end{array}$ & 8 & $62 \%$ \\
\hline $\begin{array}{l}\text { Technical assistance for faculty in } \\
\text { course and course materials } \\
\text { development }\end{array}$ & $\begin{array}{l}\text { (2); (3); (6); (7); (8); (10); } \\
\text { (11) }\end{array}$ & 7 & $54 \%$ \\
\hline Instructional design support & $\begin{array}{l}\text { (1); (2); (3); (5); (7); (10); } \\
\text { (13) }\end{array}$ & 7 & $54 \%$ \\
\hline $\begin{array}{l}\text { Support for online students with } \\
\text { special needs }\end{array}$ & (3); (5); (6); (7); (8); (9); (11) & 7 & $54 \%$ \\
\hline $\begin{array}{l}\text { Online program management } \\
\text { support }\end{array}$ & $(1) ;(4) ;(8) ;(9) ;(12) ;(13)$ & 6 & $46 \%$ \\
\hline $\begin{array}{l}\text { Intellectual property/ copyright } \\
\text { support }\end{array}$ & $(2) ;(3) ;(4) ;(5) ;(7)$ & 5 & $38 \%$ \\
\hline $\begin{array}{l}\text { Online student orientation to } \\
\text { institution }\end{array}$ & $(1) ;(2) ;(3) ;(8) ;(10)$ & 5 & $38 \%$ \\
\hline Online education research support & (4); (5); (9); (10); (11) & 5 & $38 \%$ \\
\hline $\begin{array}{l}\text { Faculty recognition and } \\
\text { compensation for transition to and } \\
\text { engagement in online education }\end{array}$ & $(3) ;(5) ;(6) ;(7) ;(9)$ & 5 & $38 \%$ \\
\hline $\begin{array}{l}\text { Online student orientation to } \\
\text { online learning/study skills }\end{array}$ & $(5) ;(6) ;(7)$ & 3 & $23 \%$ \\
\hline Learning analytics support & $(5) ;(6)$ & 2 & $15 \%$ \\
\hline
\end{tabular}




\section{Guidelines/Standards for Online Course Design}

Twelve of the 13 frameworks recommended that institutions need guidelines or standards for online course design that can either be developed within an institution or adopted from wellknown professional organizations. Most of the frameworks also included such guidelines or standards to ensure quality. These are not only useful for faculty who are transitioning to online teaching, but also provide structure and guidance for faculty revising existing online courses.

\section{Administrative and Academic Support for Online Students}

Twelve of the 13 frameworks also highlighted the importance of administrative services for online students such as student admissions, registration, and financial guidance. Although these services are categorized under online student support and not under faculty support in the frameworks, prior research has established that online student support of this nature supports faculty in focusing on online teaching. Many faculty members teaching online might not be aware of institutional procedures or resources in these areas and can be overwhelmed if they are the only point of contact for online students. The inclusion of such administrative and academic support presumes the presence of qualified staff with continuously updated expertise in supporting online faculty and students (Framework 9).

Several frameworks also included specific forms of academic support for online students that can be lessen the responsibilities and workload of faculty teaching online:

- Online tutors or tutoring services (9 of 13 frameworks) that can work with individual students or student groups and help them feel less isolated. There was variety in the conceptualization of the responsibilities of online tutors in the frameworks, yet they all assumed a supportive role to faculty and students. HEIs have to "include guidelines on how these tutors/e-tutors can best be used" (Framework 10, p. 73) and should ensure continuous professional development of those in such roles.

- Online library support services (9 of 13 frameworks) that help students access resources needed for their online courses, thus reducing the need for faculty to help online students with library access and teach them the skills needed to navigate library websites and databases;

- Online student advising services (8 of 13 frameworks) for student program questions, academic program planning, student counseling, career planning and employment counseling;

- Support for online students with special needs (7 of 13 frameworks), which can be crucial for faculty who might be unsure as to how to support online students with special needs in the online environment;

- Online student orientation to the institution (5 of 13 frameworks) that introduces online students to procedures and technologies at the institution, thus increases their familiarity with online education at the institution, and possibly decreasing the initial questions that faculty might face from new students;

- Online student orientation to online learning/study skills (3 of 13 frameworks), which helps students understand the importance of time management and self-regulation to online learning success. This responsibility often falls to faculty in the online environment who 
have to not only teach content, but also help students learn how to best approach online learning to succeed.

\section{Professional Development for Faculty in Online Course Development and Teaching}

Eleven of 13 frameworks highlighted the need for faculty professional development on various topics related to online teaching (e.g., course design, interactions, communication, and assessment), technology (e.g., the learning management system), and policies to ensure quality in online course design and teaching. An institutional environment that not only fosters faculty development of knowledge and skills related to online teaching, but also recognizes and rewards faculty engagement in such learning is needed (Framework $2 \& 5$ ). Professional development can take the form of workshops, best practice guides, seminars, symposia, peer mentoring, peer reviews, collaborative course development, and also participation in communities of practice.

Frameworks 8 highlighted the need for professional development that is "not limited by factors of physical location, equity, or technological skills...is offered flexibly, accommodates a range of entry points" and is coordinated across an institution (p. 29). Such flexibility is needed because faculty who teach online are not always full-time and located on-campus, but can be parttime and may not be connected to the institution where they teach. Professional development should not only take into account full-time faculty, but also provide learning and support opportunities that consider the needs of online faculty who may work part-time, feel isolated, and "have no regular face-to-face contact with supervisors and colleagues" (Framework 10, p. 77).

\section{Instructional Design and Technical Support}

Seven of 13 frameworks emphasized instructional design support for faculty making the transition from face-to-face to online teaching, that is not only provided before a course runs, but also during its duration. Framework 6 states that "this support should encompass both educational and technical aspects without demanding that academics become ICT or media specialists in their own right" (p. 113). Seven of 13 frameworks also recommended technical assistance for course development, which includes support in the areas of course materials development, graphic design, media development, editing, open educational resource use, and Learning Management System or Virtual Learning environment use (Framework 9). Intellectual property/ copyright support for faculty who might not be aware of an institution's intellectual property policies or fair use guidelines for online course materials were recommended by 5 of 13 frameworks as important to quality online education. This support should also include resources and training related to these topics, "plagiarism, and other relevant legal and ethical concepts" related to online education (Framework 3, p. 4).

\section{Online Program Management Support}

In addition to the administrative and academic support for online students that is essential for quality online education and helps faculty focus on interacting with students about course content, online program management support is also recommended in 9 of 13 frameworks. Support for faculty with the administration of online programs can be helpful because online programs often need additional accreditation, transfer of study credits, or other types of procedures with which faculty might not be familiar.

\section{Online Education Research Support}

Five of 13 frameworks highlight the importance of research on online education, or the scholarship of online teaching for quality online education. They recommend that faculty be 
encouraged to practice such scholarship related to their online courses, and be provided resources and support in order to do so. For example, Framework 5 suggests that "internal and external publication on pedagogic issues related to e-learning" should be encouraged (p. 26).

\section{Recognition for Engagement in Online Education}

There is a learning curve associated with the transition to online teaching and time needed for faculty to develop online courses (Framework 5), that should be acknowledged by an institution. Three of 13 frameworks recommended the provision of various types of compensation, rewards, and recognition for initial and continued online course development or online education engagement. It is important to create an environment of respect for online teaching as a "highstatus activity" (Framework 6, p. 125) to motivate faculty to adopt, engage, and excel in online teaching. Additionally, Framework 6 suggests that such recognition "be integrated into mechanisms of promotion and career development" (p. 127), while Framework 9 recommends that "promotion criteria give preference to candidates with experience and expertise" (p. 19) in online education.

\section{Discussion}

\section{Limitations}

This scoping review focused on the types of support needed by faculty teaching online that are found in frameworks, guidelines, or standards addressing quality in online education. This review was conducted in the public domain and excluded empirical literature and research that might have concluded with quality guidelines or suggestions for faculty support in online education. It also excluded frameworks or guidelines that were focused on only one aspect of online education or that did not focus on higher education, specifically. For example, the Quality Matters Higher Education rubric was not included because it pertained specifically to online course design. The exclusion and inclusion criteria we chose to apply thus limited the resulting frameworks that were analyzed. However, we clearly reported our step-by-step method in great detail so that our study is replicable, and also explicitly explained our focus on the faculty perspective in the analysis strategy so that any potential bias in the reporting can be identified (Arksey \& O’Malley, 2009).

\section{Implications}

The purpose of this study was to identify the institutional support services in online quality assurance frameworks that support quality online teaching in higher education. In this section we discuss the various types of support that were found in the frameworks

Technologies and technical support that comprise infrastructure and faculty/student access to it in online education were unsurprisingly a form of support cited in all the frameworks reviewed in this research. The collection of data about program or course effectiveness was also mentioned in all the quality assurance frameworks and considered important for faculty teaching online because of the opportunities such data provide for faculty aiming for excellence to reflect, revise, and improve their online courses (Kumar, Martin, Budhrani, \& Ritzhaupt, 2019). Institutions, however, have to make this data easily available to faculty, and, if in the form of learning analytics, provide opportunities for faculty to learn how to access and interpret such data to improve learning design (Lockyer, Heathcoate, \& Dawson, 2013). Likewise, the provision of administrative and academic support services to online students greatly lessens the need for faculty teaching online 
(Wang et al., 2010), who might not have adequate knowledge of online administrative and academic processes (e.g., registration, technical help accessing the library), to additionally support students in these processes essential for their success. Only $23 \%$ of the frameworks mentioned formal online student orientations and student orientations to online learning, which is an area that can greatly contribute to quality in online education, student success, and faculty success. Although orientations to online course structure and navigation were specified within online course design guidelines in the frameworks, self-regulation, online study skills, and time management advice for the online environment can greatly help online students (Broadbent \& Poon, 2015) and the faculty who otherwise mentor them in these areas. The provision of a formal generic orientation to these areas of online learning can also provide faculty with opportunities to focus on discipline-specific or content-specific online learning skills.

Professional development for faculty in online course development and teaching, as well as standards or guidelines for online course design were included in over $90 \%$ of the frameworks, but the provision of instructional design or technical assistance for course development and teaching were only mentioned in $54 \%$ of the frameworks reviewed. Faculty learning opportunities are essential to ensure quality in online education, but instructional design and technical support are as important to ensure excellence in online course design, development, and improvement. A "team-based approach to online course design, leveraging the talents of various specialists alongside faculty" has been positively associated with a "more well-rounded online student experience" (Garrett et al., 2019, p. 18). Financial and other resources for such support can be a challenge at certain HEIs, but a transition to online education and quality in online education can be expedited with such support. Given the increasing participation of diverse learners in online education, such instructional design support can also help faculty create course materials for learners with special needs, accessibility concerns, or from other cultures.

Support for faculty questions on fair use, plagiarism, and intellectual property was only mentioned in $38 \%$ of the frameworks, but is also greatly needed during online course development and teaching. In terms of professional development, only two of the frameworks explicitly focused on learning opportunities or online professional development for part-time faculty or online faculty who might not be physically present at an HEI. Given the high numbers of adjunct or part-time faculty who teach online, innovative, flexible, and online professional development on topics related to online teaching can help ensure the quality of online education at an institution.

Although the time taken for online course development, increased workload in online teaching, and the lack of recognition given to those teaching online are barriers faced by online faculty that are acknowledged in the literature (Bolliger \& Wasilik, 2009), only 38\% of the quality assurance frameworks reviewed recommended rewards, compensation, and recognition for online course development and teaching. Notwithstanding other forms of support, if engagement and excellence in online teaching is not lauded, and also not acknowledged in tenure and promotion processes, faculty will not be motivated to excel in online teaching. Increased workload or large class sizes in the online environment also have to be addressed with new policies informed by research in online education that support faculty in their online teaching endeavors. Such rewards and policies are needed to increase faculty satisfaction, a pillar of quality online education (https://onlinelearningconsortium.org/about/quality-framework-five-pillars/). Finally, support for the scholarship of teaching (Boyer, 1990), mentioned in only $38 \%$ of the frameworks in this study, can contribute greatly to faculty scholarship about online education, to our knowledge of faculty 
experiences with online teaching across disciplines, and to the sharing of online pedagogy and course design in various environments.

The frameworks included in this scoping review were from Canada, the US, Mexico, Brazil, South Africa, Africa, Asia, and the European Union. Frameworks from all the regions included most types of support such as technical support for students and faculty, guidelines for online course design, data collection about the effectiveness of online courses, or administrative and academic support for online students. Some types of support appeared more often within certain regions than others. For example, support for copyright considerations and legal services was mainly included in US and European frameworks, and considerations of students' digital skills as well as the use of learning analytics were emphasized in European frameworks. This could be attributed to the fact that all three European frameworks included in this review were published between 2015 and 2018 .

\section{Conclusion}

In this study, we reviewed the various types of support that ensure quality in online education, specifically from the perspective of supporting faculty members who teach online. HEIs adopt and implement online education differently depending on their institutional goals, the students and communities they seek to serve, and the resources they have available for online education. Regardless of HEI type and involvement in online education, the goal of this review is to provide a comprehensive picture of how quality faculty support of online teaching can be ensured in higher education. Faculty support for online teaching is a relevant topic in current times, where faculty are faced with a sudden transition to various forms of online or remote teaching due to COVID-19. Further research is needed on the different types of support that are needed in such a sudden transition, where faculty engage in emergency remote teaching, and in the longer term, on faculty support for blended remote teaching where faculty might have to teach students at a distance while in their classrooms. This review focused on support for faculty teaching online who play a key role in online student learning. Institutions might need further coordination and collaboration among support services for faculty teaching both online and on-campus students as boundaries between on-campus and online teaching blur and faculty prepare to teach students in both environments.

\section{Acknowledgements}

This research was conducted with support from the Fulbright Scholar Program Advanced Research and University Lecturing Award. 


\section{References}

Almpanis, T. (2015). Staff development and institutional support for Technology Enhanced Learning in UK Universities. The Electronic Journal of e-Learning, 13(4), 366-375.

Arksey, H., \& O'Malley, L. (2005). Scoping studies: towards a methodological framework. International journal of social research methodology, 8(1), 19-32.

Baran, E., \& Correia, A. P. (2014). A professional development framework for online teaching. TechTrends, 58(4), 95-101.

Beck, D., \& Ferdig, R. E. (2008). Evolving roles of online and face-to-face instructors in a lecture/lab hybrid course (Vol. 7). http://eric.ed.gov/?id=ED499577

Berge, Z. L., Muilenburg, L. Y., \& Haneghan, J. V. (2002). Barriers to distance education and training: Survey results. The Quarterly Review of Distance Education, 3(4), 409-418.

Bolliger, D. U., \& Wasilik, O. (2009). Factors influencing faculty satisfaction with online teaching and learning in higher education. Distance education, 30(1), 103-116.

Boyer, E. L. (1990) Scholarship Reconsidered: Priorities of the Professoriate. Princeton, NJ: Carnegie Foundation for the Advancement of Teaching.

Broadbent, J., \& Poon, W. L. (2015). Self-regulated learning strategies \& academic achievement in online higher education learning environments: A systematic review. The Internet and Higher Education, 27, 1-13.

Cacchione, P. Z. (2016). The evolving methodology of scoping reviews. Clinical Nursing Research, 25(2), 115-119.

Colquhoun, H. L., Levac, D., O'Brien, K. K., Straus, S., Tricco, A. C., Perrier, L., Kastner, M. \& Moher, D. (2014). Scoping reviews: time for clarity in definition, methods, and reporting. Journal of clinical epidemiology, 67(12), 1291-1294.

Daniel, J. \& Uvalic-Trumbic, S. (Eds.) (2013). A guide to quality in online learning. https://www.academicpartnerships.com/Resource/documents/A-Guide-to-Quality-in-OnlineLearning.pdf

Fetzner, M. J. (2003). Institutional support for online faculty: Expanding the model. Elements of quality online education: Practice and direction, 4, 229-241.

Garrett, R., Legon, R. \& Fredericksen, E. E., (2019). CHLOE 3 Behind the Numbers: The Changing Landscape of Online Education 2019. Quality Matters.

http:/qualitymatters.org/qa-resources/resource-center/articles-resources/CHLOE-3-report2019

Hicks, M. (2014). Professional development and faculty support. In O. Zawacki-Richter \& T. Anderson (Eds.), Online Distance Education: Towards a Research Agenda (pp. 267-286). Athabasca University Press, Canada.

Hodges, C., Moore, S., Lockee, B., Trust, T., \& Bond, A. (2020). The difference between emergency remote teaching and online learning. Educause Review, 27. Retrieved from https://er.educause.edu/articles/2020/3/the-difference-between-emergency-remote-teachingand-online-learning 
Hunt, H. D., Davies, K., Richardson, D., Hammock, G., Akins, M., \& Russ, L. (2014). It is (more) about the students: Faculty motivations and concerns regarding teaching online. Online Journal of Distance Learning Administration, 17(2), 62-71.

Kibaru, F. (2018). Supporting faculty to face challenges in design and delivery of quality courses in virtual learning environments. Turkish Online Journal of Distance Education, 19(4), 176197.

Kebritchi, M., Lipschuetz, A., \& Santiague, L. (2017). Issues and challenges for teaching successful online courses in higher education: A literature review. Journal of Educational Technology Systems, 46(1), 4-29.

Kumar, S., Martin, F., Budhrani, K., \& Ritzhaupt, A. (2019). Award-winning faculty online teaching practices: Elements of award-winning courses. Online Learning Journal, 23(4). https://olj.onlinelearningconsortium.org/index.php/olj/article/view/2077

Levac, D., Colquhoun, H., \& O'Brien, K. K. (2010). Scoping studies: advancing the methodology. Implementation science, 5(69).

https://link.springer.com/article/10.1186/1748-5908-5-69

Lion, R. W., \& Stark, G. (2010). A glance at institutional support for faculty teaching in an online learning environment. Educause Quarterly, 33(3), 23-39.

Lloyd, S. A., Byrne, M. M., \& McCoy, T. S. (2012). Faculty-perceived barriers of online education. MERLOT Journal of online learning and teaching, 8(1), 1-12.

Lockyer, L., Heathcote, E., \& Dawson, S. (2013). Informing Pedagogical Action Aligning Learning Analytics with Learning Design. American Behavioral Scientist, 57(10), 14391459.

Martin, F., Budhrani, K., Kumar, S., \& Ritzhaupt, A. (2019). Award-winning faculty online teaching practices: Roles and competencies. Online Learning Journal, 23(1), 184-205.

Martin, F. \& Parker, M.A. (2014). Use of synchronous virtual classrooms: Why, who and how? MERLOT Journal of Online Learning and Teaching, 10(2), 192-210.

Martin, F., Polly, D., Jokiaho, A., \& May, B. (2017). Global standards for enhancing quality in online learning. The Quarterly Review of Distance Education, 18(2), 1-10.

Orr, R., Williams, M. R., \& Pennington, K. (2009). Institutional efforts to support faculty in online teaching. Innovative Higher Education, 34(4), 257-268.

Peterson, J., Pearce, P. F., Ferguson, L. A., \& Langford, C. A. (2017). Understanding scoping reviews: Definition, purpose, and process. Journal of the American Association of Nurse Practitioners, 29(1), 12-16.

Phirangee, K., Epp, C. D., \& Hewitt, J. (2016). Exploring the relationships between facilitation methods, students' sense of community, and their online behaviors. Online Learning, 20(2), $134-154$.

Seaman, J. (2009). Online Learning as a Strategic Asset. Volume II: The Paradox of Faculty Voices-Views and Experiences with Online Learning. Results of a National Faculty Survey, Part of the Online Education Benchmarking Study Conducted by the APLU-Sloan National Commission on Online Learning. Association of Public and Land-Grant Universities. 
Seaman, J. E., Allen, I. E., \& Seaman, J. (2018). Grade increase: Tracking distance education in the United States. Babson Survey Research Group.

Shelton, K. (2011). A rfeview of paradigms for evaluating the quality of online education programs. Online Journal of Distance Learning Administration, 14(1). https://www.westga.edu/ distance/ojdla/spring141/shelton141.html

Wang, H., Gould, L. V., \& King, D. (2009). Positioning faculty support as a strategy in assuring quality online education. Innovate: Journal of Online Education, 5(6). 